\title{
ECONOMIC LOSSES OF NON-EXCLUSIVE BREASTFEEDING IN EAST NUSA TENGGARA
}

\author{
Oleh: \\ Estro Dariatno Sihaloho ${ }^{1}$ \\ Rahma $^{2}$ \\ Wandira Larasati Senja ${ }^{3}$ \\ Pipit Pitriyani $^{4}$ \\ Adiatma Y.M Siregar ${ }^{5}$ \\ ${ }^{1}$ Department of Economics, Padjadjaran University \\ ${ }^{2}$ Master Economics Program of Lund University \\ ${ }^{3}$ The SMERU Research Institute \\ E-mail: \\ estro.sihaloho@unpad.ac.id
}

\begin{abstract}
ABSTRAK
Pengetahuan tentang pentingnya menyusui yang ekslusif masih rendah di Nusa Tenggara Timur. Banyak keluarga yang mulai menyediakan makanan pendamping seperti pisang atau bubur untuk bayi mereka sejak berusia 2 bulan. Menyediakan makanan pendamping kepada bayi sejakberumur 2 bulanakan meningkatkan kemungkinan diare dan pneumonia/ pernapasan bayi. Penelitian ini memiliki tiga tujuan. Tujuan pertama mencoba memperkirakan dampak ekonomi dari menyusui yang tidak memadai di Nusa Tenggara Timur. Tujuan kedua mencoba untuk menghitung biaya medis sistem kesehatan dan tujuan ketiga mencoba untuk menghitung biaya pasien / non-medis. Penelitian ini menghitung biaya pasien dari 153 data pasien yang dikumpulkan dari Kabupaten Kupang pada 2016. Penelitian ini memperkirakan dampak ekonomi dengan menggabungkan biaya sistem kesehatan, biaya pasien / non-medis dengan data prevalensi dari IDHS 2012. Penelitian ini menemukan bahwa total kerugian ekonomi yang bisa diakibatkan ASI tidak ekslusif yang berhubungan dengan penyakit diare dan pernafasan sebesar US\$2,718,497. Penelitian ini menemukan bahwa rata-rata biaya yang dikeluarkan karena pemberian ASI tidak ekslusif adalah sebesar US\$ 9.3 untuk penyakit diare dan US\$8.4 untuk penyakit pernafasan.
\end{abstract}

Kata Kunci: Kerugian Ekonomi, ASI Tidak Ekslusif, Analisis Ekonomi, Nusa Tenggara Timur 


\begin{abstract}
The knowledge of the importance of exclusive breastfeeding is still low in East Nusa Tenggara. Many families have started providing complementary foods like bananas or porridge, to their babies when they are only 2 months old. Providing complementary foods since babies 2 months old will increase the possibility of diarrhea and pneumonia/respiratory of babies. This study has three objectives. The first objective tries to estimate the economic impact of non-breastfeeding in East Nusa Tenggara. The second objective tries to calculate the health system medical cost and the third objective tries to calculate the patient/non-medical cost. This paper calculates the patient cost from 153 patient data collected from Kupang district in 2016. This paper estimates the economic impact by combining the health system cost, patient/non-medical cost with the prevalence data from IDHS 2012. This study finds that total economic losses caused by non-exclusive breastfeeding due to diarrhea and pneumonia/respiratory about US\$ 2,718,497. This study finds the average cost due to non-exclusive breastfeeding for diarrhea cases about US\$ 9.3 and PRD cases about US\$8.4.
\end{abstract}

Keywords: Economic Losses, Non-Exclusive Breastfeeding, Economic Analysis, East Nusa Tenggara

\title{
A. INTRODUCTION
}

East Nusa Tenggara is one of the eastern provinces of Indonesia with a population of 5,120,061 in 2015 (Badan Pusat Statistik Nusa Tenggara Timur, 2016). In 2016, East Nusa Tenggara is divided into 22 administrative regions consisting of 22 districts and one city. East Nusa Tenggara is one of the provinces that include to the medium category of Indonesia provinces HDI with HDI of 62.67. While for the life expectancy of 65.96, East Nusa Tenggara entered into the low category compared with other provinces in Indonesia. The HDI and life expectancy of East Nusa Tenggara become the figure of HDI and life expectancy condition of provinces in eastern (Badan Pusat Statistik, 2016). Life expectancy is an indicator that can show the quality of public health in an area. Low life expectancy of East Nusa Tenggara shows that the quality of health dimension of East Nusa Tenggara is still quite low. The Government of East Nusa Tenggara tries various ways to improve health services to the society that covers the entire population from infants to the elderly.

The Government of East Nusa Tenggara also began to pay attention to the quality of children's health from an early age by improving the birth service and watch the nutritional status of children. One of the steps taken by the government to improve the nutritional status of children in East Nusa Tenggara is by increasing exclusive breastfeeding. Many factors that cause babies in East Nusa Tenggara are not exclusively breastfed. Breastfeeding is associated with a wide range of positive health outcomes in children and mothers. This is related to a lot of diseases like respiratory infection, asthma (Liu, Leung, \& Yang, 2013). Breast milk contains nutrients rich in antibodies and maintains infant health and growth. There is large evidence for the protective effects of breastfeeding against diarrhea 
incidence(Lamberti et al., 2013). There is also large evidence that pneumonia mortality was higher among partially compared to exclusively breastfed (Lamberti, Fischer Walker, Noiman, Victora, \& Black, 2011).

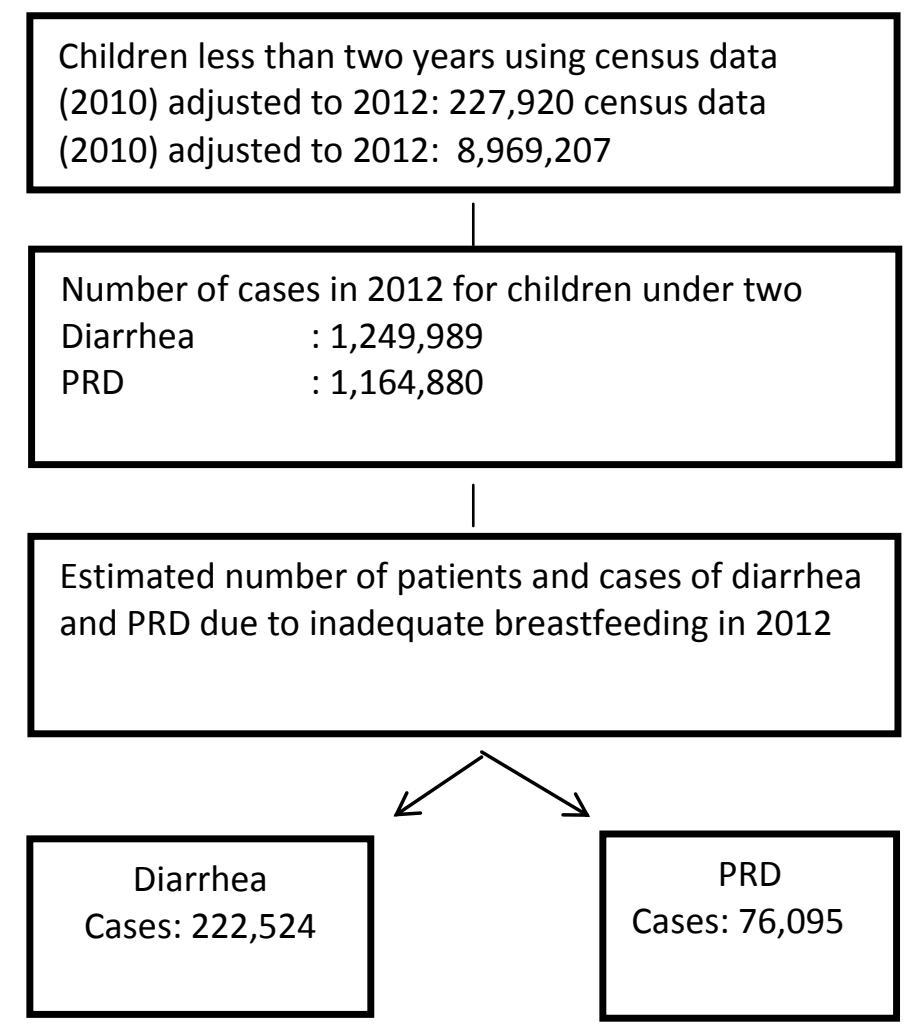

Figure 1.

The Number of Diarrhea and PRD Cases Calculation In East Nusa Tenggara

Source: Census of Indonesia 2010 and IDHS 2012, estimated (Siregar, Pitriyan, \& Walters, 2018)

The figure shows that there are 227.920 children less than two years old in East Nusa Tenggara. This number has adjusted to 2012 condition from the census data in 2010. From the number, estimated numbers of diarrhea cases were $1,249,989$ and PRD cases were $1,164,880$ in 2012. But not all cases of diarrhea and PRD are caused by a lack of exclusive breastfeeding. There were 222,524 cases and 76,095 cases of PRD due to inadequate breastfeeding in 2012. This number was huge and absolutely will give big bad impact to the health quality of society. This is also will cause huge cost that the government and society must pay.

This study elaborates the economic cost of non-exclusive breastfeeding, caused by treatment costs of diarrhea and PRD among children (under 2 years old). This study can be a recommendation for government and society into action to improve breastfeeding policies and practices in East Nusa Tenggara. 


\section{B. DATA AND METHODS}

\section{Data Description}

This research used primary data and secondary data. The primary data source was interview results from one public hospital and two primary health center in Kupang Regency in 2016. Accompanying family members of the babies with diarrhea or PRD was interviewed about 18 people from the public hospital (Naibonat Hospital) and 135 people from the two health centers (Naibonat Puskemas and Camplong Puskemas) were interviewed, totaling 153 respondents. The secondary data was from the Statistics Bureau of Indonesia 2010 and IDHS 2012. This research focuses on measuring the total economic impact of inadequate breastfeeding in East Nusa Tenggara by calculating the health system medical cost and patient/non-medical cost.

\section{Methods}

This research uses a costing analysis method. Costing analysis can be useful to improve budgeting by monitoring costs and improve the intervention efficiency by identifying the potential cost saving (UNAIDS, 2000). This paper tries to analyze the costs for the health care system due to inadequate breastfeeding in East Nusa Tenggara. The costing analysis of the health care system divided into medical costs and non-medical costs. The medical cost was directly correlated to the treatment process. Supply costs (both recurrent and capital items), health worker salary was collected to calculated the medical cost. Interviews with one health worker per facility were collected to find the percentage of health staff participation and utilization of capital items for pneumonia and diarrhea treatment. Transportation costs, time costs, administration costs, family costs were collected to calculate the non-medical costs by interviewed the accompanying family members. When the babies with diarrhea or PRD accompanied by the family members come to the facility, the family members will lose productivity. This paper use average cost of non-exclusive breastfeeding of Regency of Kupang as the average cost of non-exclusive breastfeeding for East Nusa Tenggara due to Expert Opinion from Ministry of Health, Indonesia.

\section{RESULT}

Province of East Nusa Tenggara has a unique health system. People are encouraged to come to the primary health center for the first treatment. When the primary health center can't give medicinal treatment, the health staff will be referred to the public hospital. From the interview results, people in East Nusa Tenggara tend not to go directly to the facilities when they got sick. After a few days or a week, they are still sick; they will go to the primary health center. The parents probably also do the same with their babies if their babies got sick.

Table 1 shows the characteristics of accompanying family members for babies that got treatment due to diarrhea or PRD in one public hospital and two primary health centers. The table shows that the average age of accompanying family members is 33 years old in hospital and 31 in primary health centers. Most 
accompanying family members are female, mostly their mothers with $72 \%$ in hospital and $97 \%$ in the primary health center. There are 17 accompanying family members in the hospital and 47 accompanying family members in the primary health center that worked.

Table 1.

Accompanying family member(s) characteristics ( $n=18$ for public hospital and $n=135$ for primary health center)

\begin{tabular}{lcc}
\hline \multirow{2}{*}{ Items } & \multicolumn{2}{c}{ Type of facility } \\
\cline { 2 - 3 } & Public Hospital & $\begin{array}{c}\text { Primary Health } \\
\text { Center } \\
\text { (Puskesmas) }\end{array}$ \\
\hline Age (mean) & $33(26-43)$ & $31(19-50)$ \\
Female & $13(72 \%)$ & $132(97 \%)$ \\
Employed & $16(89 \%)$ & $47(36 \%)$ \\
Education (high school or higher) & $12(63 \%)$ & $61(45 \%)$ \\
Marital status(married) & $17(94 \%)$ & $128(95 \%)$ \\
Number of children(mean) & 2 & 3 \\
Journey time length in minutes, & $32(10-120)$ & $19(2-120)$ \\
mean(min-max) & & $18(5-120)$ \\
Time spent in hospital in minutes, & $92(40-180)$ & $50(58)$ \\
mean(min-max) & $107(91)$ & $17(12 \%)$ \\
Monthly expenditure, USD Mean & & $85(63 \%)$ \\
Patient type of disease & $3(17 \%)$ & $3(25 \%)$ \\
Diarrhea & $10(56 \%)$ & \\
ARI & $5(27 \%)$ & \\
Diarrhea and ARI & & \\
\hline
\end{tabular}

*Exchange rate Rp. 13,120/US\$ (The World Bank, 2016)

The table also shows that average journey time to the hospital with 32 minutes was longer than the primary health center with 19 minutes. This shows us that the primary health center is more accessible than the hospital. The average length of time spent in the hospital also longer than in primary health center. The patients must spend 94 minutes in hospital, five times longer than the primary health center with just 18 minutes. The transport time and spending time in facilities will cause productivity loss of the accompanying family members.

Table 2 provides the costs of outpatient and inpatient service related to diarrhea and PRD in Naibonat hospital. The patient cost was calculated by adding up the transport costs, family costs, productivity loss and treatment-related costs like lab and registration. This research estimated the total cost per year for 285 outpatient visits and 114 inpatient visits per year in Naibonat hospital. For the total cost (societal perspective), the table shows that the unit cost per outpatient for total with $\$ 13.53$ is lower than the unit cost per inpatient at $\$ 167.36$. The 
total patient cost for an inpatient with $\$ 4,405.07$ was larger than outpatient with $\$$ 2,384.09. The larger patient cost caused by longer productivity loss for the inpatient.

Table 2.

Cost of outpatient and inpatient services for diarrhea and PRD, at a public hospital in Kupang Regency

\begin{tabular}{|c|c|c|c|c|c|}
\hline \multirow[b]{2}{*}{ Items } & \multicolumn{5}{|c|}{ Total Cost of Treatment (US\$) } \\
\hline & $\begin{array}{c}\text { Medical } \\
\text { Equipment } \\
\text { and } \\
\text { Furniture/Space } \\
\end{array}$ & $\begin{array}{c}\text { Supplies } \\
\text { (Medicines } \\
\text { ) }\end{array}$ & $\begin{array}{l}\text { Health } \\
\text { worker }\end{array}$ & $\begin{array}{l}\text { Patient } \\
\text { Cost } \wedge\end{array}$ & $\begin{array}{c}\text { Total } \\
\text { (societal } \\
\text { perspective } \\
\text { ) }\end{array}$ \\
\hline \multicolumn{6}{|l|}{ Outpatient } \\
\hline Total Costs per year & 29.34 & 434.45 & 977.23 & $\begin{array}{c}2,384.0 \\
9\end{array}$ & $3,855.63$ \\
\hline $\begin{array}{l}\text { Unit cost per patient } \\
\text { visit }\end{array}$ & 0.10 & 1.52 & 3.43 & 8.37 & 13.53 \\
\hline \multicolumn{6}{|l|}{ Inpatient } \\
\hline Total Costs per year & 357.15 & 141.01 & $\begin{array}{c}13,603.0 \\
2\end{array}$ & $\begin{array}{c}4,405.0 \\
7\end{array}$ & $19,079.23$ \\
\hline $\begin{array}{l}\text { Unit cost per } \\
\text { patient visit }\end{array}$ & 3.13 & 1.24 & 119.32 & 38.64 & 167.36 \\
\hline
\end{tabular}

*Exchange rate Rp. 13,120/US\$ (The World Bank, 2016)

Table 3 provides the costs of outpatient service related to diarrhea and PRD in Naibonat primary health center and Camplong primary health center. The costs calculation in primary health center only for outpatient because the primary health center doesn't provide the inpatient facility. The primary health centers have more patients than the hospital because all the patients will refer to the primary health center for the first visit.

Table 3.

Costs of outpatient services for diarrhea and PRD on a primary health center in Kupang

\begin{tabular}{cccccc}
\hline & \multicolumn{5}{c}{ Total Cost of Treatment(US\$) } \\
\cline { 2 - 5 } Items & $\begin{array}{c}\text { Medical } \\
\text { Equipment and } \\
\text { Furniture/Space }\end{array}$ & $\begin{array}{c}\text { Supplies } \\
\text { (Medicines) }\end{array}$ & $\begin{array}{c}\text { Health } \\
\text { worker }\end{array}$ & $\begin{array}{c}\text { Patient } \\
\text { Cost }\end{array}$ & $\begin{array}{c}\text { Total } \\
\text { (societal } \\
\text { perspective) }\end{array}$ \\
\hline Total Costs per year & 74.4 & $5,728.8$ & 892.8 & $11,383.2$ & $18,153.6$ \\
Unit cost per patient visit & 0.01 & 0.77 & 0.12 & 1.53 & 2.44 \\
\hline
\end{tabular}

*Exchange rate Rp 13,120/US\$ (The World Bank, 2016)

For the total cost (societal perspective), the outpatient unit cost in the primary health center with $\$ 2.44$ is lower than the hospital with $\$ 13.53$. For the patient cost, the unit cost also lower in the primary health center with $\$ 1.53$ per 
visit compared to $\$ 8.37$ in the hospital. This is proved by transport time and spending time in the hospital is longer than the primary health center. This is will cause more productivity loss of accompanying family members in the hospital.

Table 4.

Diarrhea and PRD outpatient and inpatient treatment (medical and nonmedical) costs in Indonesia for infants receiving inadequate breastfeed in East Nusa Tenggara*

\begin{tabular}{|c|c|c|c|c|c|c|c|c|}
\hline \multirow[b]{2}{*}{ Items } & \multicolumn{2}{|c|}{ Public hospital } & \multicolumn{2}{|c|}{$\begin{array}{c}\text { Primary health } \\
\text { center } \\
\text { (puskesmas) }\end{array}$} & \multicolumn{2}{|c|}{ Others } & \multicolumn{2}{|c|}{ Total } \\
\hline & $\begin{array}{c}\text { Diarrhe } \\
\text { a }\end{array}$ & PRD & $\begin{array}{c}\text { Diarrhe } \\
\text { a }\end{array}$ & PRD & $\begin{array}{l}\text { Diarrhe } \\
\text { a }\end{array}$ & PRD & $\begin{array}{c}\text { Diarrhe } \\
\text { a }\end{array}$ & $\begin{array}{c}\text { PR } \\
\text { D }\end{array}$ \\
\hline \multicolumn{9}{|l|}{ Outpatient } \\
\hline Costs per year & 29,562 & $\begin{array}{c}31,12 \\
9\end{array}$ & $\begin{array}{c}113,22 \\
8\end{array}$ & $\begin{array}{c}46,36 \\
0\end{array}$ & $\begin{array}{c}785,19 \\
9\end{array}$ & $\begin{array}{c}503,72 \\
5\end{array}$ & & \\
\hline $\begin{array}{l}\text { Cost per case } \\
\text { treated } \\
\text { Inpatient }\end{array}$ & 7.2 & 17.66 & 2.54 & 2.53 & 4.6 & 9.03 & & \\
\hline Costs per year & $\begin{array}{c}529,32 \\
5\end{array}$ & $\begin{array}{c}41,11 \\
1\end{array}$ & $\mathrm{n} / \mathrm{a}$ & $\mathrm{n} / \mathrm{a}$ & $\mathrm{n} / \mathrm{a}$ & $\mathrm{n} / \mathrm{a}$ & & \\
\hline $\begin{array}{l}\text { Cost per case } \\
\text { treated }\end{array}$ & 200.33 & $\begin{array}{c}254.3 \\
7\end{array}$ & $\mathrm{n} / \mathrm{a}$ & $\mathrm{n} / \mathrm{a}$ & $\mathrm{n} / \mathrm{a}$ & $\mathrm{n} / \mathrm{a}$ & & \\
\hline $\begin{array}{l}\text { Total cost } \\
\text { (000US\$) }\end{array}$ & & & & & & & 2,075 & 643 \\
\hline Per patient & & & & & & & 9.3 & 8.4 \\
\hline
\end{tabular}

*Exchange rate Rp 13,120/US\$

Table 4 shows the total loss due to inadequate breastfeeds in East Nusa Tenggara. The table shows the total yearly cost for both diarrhea and PRD are US\$ 2,718,497 with average cost about US\$ 9.10. East Nusa Tenggara must pay costs about US\$2,075,459 for diarrhea and US\$ 643,038 for PRD. The total cost consist of a health system perspective cost about US\$1,974,278 and patient costs about 744,219. This show that most of the cost comes from the health system cost/medical cost about $72.63 \%$ and the $27.37 \%$ borne from the patient costs and non-medical cost. The table shows that the outpatient costs both from diarrhea and PRD larger in primary health center than a hospital. This had caused by a larger number of outpatient in a primary health center than a hospital.

\section{CONCLUSION}

The costing process shows that East Nusa Tenggara has to pay substantial losses about the US $\$ 2,718,497$ because the government and the public must pay the cost of diarrhea and PRD treatment caused by inadequate breastfeeding. The society also has to gain additional losses because they have lost their productivity to accompany their sick babies to the facilities. By comparison, the government of Nusa Tenggara Timur had allocated government budget for the health sector about 
the US \$12,629,192 in 2012(Directorate General of Fiscal Balance of Indonesia, 2016). If from US $\$ 2,718,497$, the government should spend the US $\$ 1,974,278$ on health system costs due to inadequate breastfeeding, indicating that the government has spent $15.6 \%$ of the health budget only to finance diarrhea and PRD due to inadequate breastfeeding. This is a huge loss for East Nusa Tenggara. The Government of East Nusa Tenggara should begin to seriously make policies to provide a campaign of the importance of exclusive breastfeeding and require all health staff to provide sufficient information to the entire society. 


\section{REFERENCES}

Badan Pusat Statistik. (2016). Indeks Pembangunan Manusia 2015. Badan Pusat Statistik.

Badan Pusat Statistik Nusa Tenggara Timur. (2016). Nusa Tenggara Timur Dalam Angka 2016.

Directorate General of Fiscal Balance of Indonesia. (2016). APBD, Realisasi $A P B D$, dan Neraca. Jakarta. Retrieved from http://www.djpk.depkeu.go.id/?page_id=316

Lamberti, L. M., Fischer Walker, C. L., Noiman, A., Victora, C., \& Black, R. E. (2011). Breastfeeding and the risk of diarrhea morbidity and mortality. BMC Public Health. https://doi.org/10.1186/1471-2458-11-S3-S15

Lamberti, L. M., Zakarija-Grković, I., Fischer Walker, C. L., Theodoratou, E., Nair, H., Campbell, H., \& Black, R. E. (2013). Breastfeeding for reducing the risk of pneumonia morbidity and mortality in children under two: A systematic literature review and meta-analysis. BMC Public Health. https://doi.org/10.1186/1471-2458-13-S3-S18

Liu, J., Leung, P., \& Yang, A. (2013). Breastfeeding and active bonding protect against children's internalizing behavior problems. Nutrients. https://doi.org/10.3390/nu6010076

Siregar, A. Y. M., Pitriyan, P., \& Walters, D. (2018). The annual cost of not breastfeeding in Indonesia: The economic burden of treating diarrhea and respiratory disease among children $(<24 \mathrm{mo})$ due to not breastfeeding according to the recommendation. International Breastfeeding Journal, 13(1), 1-10. https://doi.org/10.1186/s13006-018-0152-2

UNAIDS. (2000). Costing Guidelines for HIV Prevention. October. 